\title{
Компартмент-синдром кінцівок та черевної порожнини
}

\begin{abstract}
Мета роботи: оцінити власний досвід діагностики та лікування компартмент-синдрому (КС) кінцівок та черевної порожнини. Матеріали і методи. Проведений аналіз клінічного перебігу, діагностики та лікування КС у 5 пацієнтів.

Результати досліджень та їх обговорення. КС верхньої кінцівки спостерігали у 2 хворих, нижньої - в одного. У всіх пацієнтів ознаки КС виникли через 3 тижні після первинного ураження. В одному спостереженні після укусу собаки спостерігали значне підвищення активності трансаміназ. Виконання декомпресії фасціальних футлярів та проведення антиклостридіальної антибактеріальної терапії впродовж 23 діб дозволило досягти повного одужання пацієнта. В другому спостереженні травма плеча на тлі приймання варфарину супроводжувалась наростанням підфасціальної гематоми. Застосування іншого препарату антикоагулянтної дії та здійснення фасціотомії сприяло одужанню. В обох пацієнтів за даним ультразвукового дослідження виявлено втрату структурності та набряк м’язів. Патогномонічність цих ознак слід перевірити в подальших дослідженнях. У третього пацієнта з КС, тотальною підшкірною та міжм’язовою флегмоною гомілки та стегна на тлі лімфостазу виконано ампутацію кінцівки на рівні верхньої третини стегна.

Інтраабдомінальну гіпертензію (ІАГ) на рівні 20 мм рт. ст. і вище в перші 3 доби після внутрішньочеревного операційного втручання спостерігали у 12 пацієнтів. Завдяки інтенсивній терапії у 9 пацієнтів нормалізувались гемодинаміка, дихання та показники метаболізму та внутрішньочеревний тиск. У 3 пацієнтів хірургічні ускладнення зумовили виконання релапаротомії. Абдомінальний компартмент-синдром (АКС) спостерігали у 2 хворих. Стан одного хворого був помилково оцінений як неадекватне поповнення водно-електролітного балансу. Продовжено інтенсивну терапію з позитивним балансом 3200 мл. В подальшому виникли ниркова недостатність та рецидивуючий сепсис, лікування яких впродовж 27 діб виявилось неефективним. Ще у одного хворого своєчасна діагностика АКС і проведення адекватної терапії супроводжувались швидким одужанням. Компартмент-синдром кінцівок та черевної порожнини є небезпечним для життя ускладненням, яке має особливі прояви і потребує спеціального лікування.
\end{abstract}

Ключові слова: компартмент-синдром; кінцівки; черевна порожнина.

Постановка проблеми і аналіз останніх досліджень та публікацій. Термін компартментсиндром (KC) використовується для позначення поліогранної недостатності, що виникає на тлі надмірного стиснення кінцівки, а також високого тиску в черевній порожнині $[1,2]$.

При своєчасному застосуванні повноцінної інтенсивної терапії, виконанні фасціотомії на кінцівці або декомпресійної лапаротомії КС вдається усунути. В разі несвоєчасної діагностики і неповноцінного лікування летальність становить 49,7 \%, а серед пацієнтів, які одужали, частота виконання ампутації кінцівки досягає 50 \%, частота порушень функції в наслідок атрофії м'язів та незворотного ураження нервів становить 30-100 \% $[3,4]$.

Покращення результатів лікування КС пов’язане з поглибленням розуміння особливостей виникнення та перебігу захворювання.

Мета роботи: оцінити особливості діагностики та лікування КС на тлі ураження кінцівок та черевної порожнини на підставі аналізу власного досвіду.

Матеріали і методи. Проведений аналіз клінічного перебігу, діагностики та лікування КС у 5 пацієнтів.
Результати досліджень та їх обговорення. Виникнення КС верхньої кінцівки, не пов'язаного 3 травмою, який автори дослідження [4] назвали спонтанним, відмічено за даними огляду літератури лише у 19 пацієнтів. Причинами ураження були порушення, пов’язані з кровотечею в 3 спостереженнях, прийом системних антикоагулянтів в 3 , інфекція в 6, системний склероз, синдром EhlersDanlos, рабдоміоліз, хвороба McArdle по одному спостереженню, причина не встановлена в 3 .

Ми спостерігали КС верхньої кінцівки у 2 хворих, нижньої в одного. Причинами виникнення КС були укус собаки (одне спостереження), гематома на тлі приймання варфарину (1), поширена і глибока міжм’язова флегмона (1).

В усіх спостереженнях клінічні ознаки КС виникли через 3 тижні після первинного ураження.

У хворого віком 33 роки після укусу собаки місце ураження на кисті повністю загоїлось, а через 3 тижні на верхній третині передпліччя та нижній третині плеча виникли гіперемія шкіри, набряк кінцівки. Хворий звернувся по лікування через 48 годин після появи гіперемії та набряку. Ознаки формування гнійного вогнища були відсутні. Призначена системна та місцева антибактеріальна та протизапальна терапія. Через 24 години ефект лікування оцінений як не значний, хворому запро- 
поноване виконання фасціотомії, від чого він відмовився. Однак через 48 годин біль посилився до рівня нестерпного, виникли парестезії, хворий скаржився на відсутність рухів пальцями кисті.

За даними ультразвукового дослідження відмічено набряк не тільки підшкірної основи, але і м’язів із втратою їх структурності. В аналізі крові активність АЛТ склала 142 од/л, АСТ 183 од/л.

Здійснена фасціотомія всіх футлярів на передпліччі та плечі. Під час операції стан м’язів оцінений як “варений”, після розсічення фасцій відповідні м’язи збільшились на 80-100 \% в об’ємі і випинались у рану. Ні в підшкірній основі, ні між м’язами скупчення гною не виявлені.

Встановлений діагноз клострідіальної негазоутворюючої анаеробної флегмони плеча та передпліччя, ускладненої ВКС. Призначений кліндаміцин 600 мг чотири рази на добу. Ще через 24 години, зважаючи на неповне відновлення рухів пальцями, рівень АЛТ 182 од/л, АСТ 120 од/л, розширена фасціотомія на передпліччі. Через 24 години рухи пальців повністю відновились. Однак в аналізі крові виявлені токсична зернистість гранулоцитів +++, мієлоцити 0,02, метамієлоцити 0,02, паличкоядерні гранулоцити 0,10, сегментоядерні гранулоцити 0,45, рівень АЛТ 142 од/л, АСТ 183 од/л, сечовини 6,5 ммоль/л, креатиніну 135 мкмоль/л.

Нормалізація лейкоцитарної формули крові та рівня гемоглобіну досягнута через 20 днів, після чого рани зашиті вторинними швами, тривалість призначення кліндаміцину склала 23 дні. Однак навіть на цей час рівень АЛТ становив 76 од/л, ACT 38 од/л. При контрольному огляді через один місяць наявний набряк кисті, чутливість шкіри та рухи пальцями в повному обсязі.

У хворого віком 64 роки КС верхньої кінцівки на тлі приймання варфарину виник через 3 тижні після ії забою. Крововилив в нижній третині правого плеча, що утворився відразу після забою, через 4 дні ускладнився наростанням набряку кінцівки та наростанням субфасціальної гематоми. Лише через 14-15 діб виникли біль та обмеження рухів плечем, які через 3 дні ускладнились появою парестезій та неможливістю рухів пальцями. Діаметр на рівні верхньої третини правого плеча 42,5 см, лівого 38 см, на рівні середньої третини правого плеча 46,5 см, лівого 36 см, на рівні нижньої третини правого плеча 43,5 см, лівого 34 см, на рівні верхньої третини правого передпліччя 38,5 см, лівого 33 см, на рівні середини передпліччя правого 36 см, лівого 30 см. При цьому в крові рівень лейкоцитів склав 7,8 x 10\%/л, загального білірубіну 46,4 мкмоль/л, АЛТ 100 од/л, АСТ 48 од/л, сечовини 7,8 ммоль/л, креатиніну 98 мкмоль/л.
Хворому виконана широка фасціотомія всіх футлярів на правому плечі та передпліччі. Через одну добу відновились рухи пальцями, через 3 доби настала нормалізація рівнів АЛТ та АСТ. Через 10 днів рани зашиті вторинними швами.

При огляді через 3 місяці чутливість шкіри правої верхньої кінцівки повна, рухи пальців без обмежень.

У третього пацієнта КС виник як ускладнення тотальної підшкірної та міжм’ язової флегмони гомілки та стегна, що розвинулись впродовж трьох тижнів на тлі вираженого хронічного лімфостазу нижньої кінцівки. Поширеність гнійного розплавлення тканин зумовила безперспективність збереження кінцівки, що одночасно з ознаками КС стало підставою для виконання високої ампутації на рівні верхньої третини стегна. Пацієнт одужав.

В першому з наведених спостережень тривалість набряку понад 96 годин зумовила значне підвищення активності трансаміназ. Це є свідченням ураження м’язів, що супроводжується ураженням печінки і є потенційно небезпечним для життя. Одночасно ураження нервів, яке проявлялось неможливістю активних рухів пальцями, становило загрозу розвитку парезу та паралічу кінцівки. За вказаних обставин лише своєчасне створення декомпресії фасціальних футлярів дозволяє сподіватись на відновлення м'язів та нервів. Однак оскільки причиною захворювання стала клостридіальна неспороутворювальна інфекція, яка сама по собі становить загрозу для життя, комплекс лікування доповнений відповідною потужною антибактеріальною терапією.

Важливо, що поступове зниження рівнів трансаміназ почалось лише через 48 годин після початку комплексного лікування, нормалізація формули крові досягнута лише через три тижні, а нормалізація активності трансаміназ вимагала ще більше часу.

В другому спостереженні виникнення крововиливу після травми плеча на тлі приймання варфарину спочатку не викликало занепокоєння. Однак подальший перебіг подій свідчить про необхідність застосування особливої тактики лікування таких пацієнтів. Оскільки приймання варфарину супроводжується незгортанням крові, виникнення гематоми слід вважати показанням до переходу на застосування іншого препарату антикоагулянтної дії, а також здійснення ультразвукового контролю за станом гематоми та м'язів і досягнення зупинки кровотечі. Результати контролю визначать розсмоктування гематоми або необхідність корекції антикоагулянтної терапії.

Наші дані свідчать про важливість оцінки клінічних та проявів та даних лабораторних дослі- 
джень для діагностики КС кінцівок. Інші дослідники [4] також вказують на відсутність патогномонічних ознак та віддають перевагу клінічній оцінці при виборі тактики лікування хворого, відмічають недостатню точність і достовірність результатів вимірювання субфасціального тиску для прийняття рішення про здійснення фасціотомії.

У наших спостереженнях за допомогою ультразвукового дослідження були виявлені втрата структурності та набряк м'язів у хворих з клінічними проявами КС. Але, через невелику кількість спостережень, патогномонічність цих ознак слід перевірити в подальших дослідженнях.

Абдомінальний компартмент-синдром (АКС) має більш складний патогенез, ніж КС кінцівок, що зумовлює більші складності для встановлення діагнозу та проведення лікування [5, 6].

Згідно $з$ міжнародним консенсусом 2013 р., АКС визначається як стійке підвищення внутрішньочеревного тиску більше 20 мм рт. ст., що супроводжується виникненням порушення/недостатності функції органів [1].

Розрізняють первинний (П) та вторинний (В) AKC [5]. ПАКС вважають такий, що виник після травми або гострого захворювання з ураженням органів черевної порожнини або заочеревинного простору, а ВАКС такий, за якого вогнище первинного ураження не пов'язане з черевною порожниною. Причинами виникнення абдомінального ПАКС можуть бути тяжка внутрішньочеревна інфекція, панкреатит, тупа або відкрита травма живота, розрив аневризми аорти, післяопераційна кровотеча, заочеревинна кровотеча, надмірне стиснення живота при лікуванні грижі, асцит, кишкова непрохідність, вагітність. Ці ж дослідники причинами ВАКС вважають сепсис, внутрішньовенне введення великих об'ємів рідини, великий опік, тривалий амбулаторний перитонеальний діаліз, ожиріння.

Однак для практики вказаний розподіл причин АКС мало корисний, оскільки не викликає потреби диференційованого застосування засобів діагностики та лікування.

Поняття первинного або вторинного виникнення АКС важливе, якщо оцінювати проміжок часу від первинного абдомінального втручання до появи ознак АКС.

Важливою відмінністю АКС $є$ поєднання високого внутрішньочеревного тиску з поліорганною недостатністю.

Ми спостерігали підвищення внутрішньочеревного тиску до 20 мм рт. ст. і вище в перші 3 доби після проведення планового внутрішньочерев- ного операційного втручання у 12 пацієнтів. 3 них у 6 проводилась штучна вентиляція легень впродовж 2-3 діб, у 3 застосовувалось постійне введення симпатоміметиків для підтримання гемодинаміки, у 8 рівень сечовини підвищився в крові більше 12 ммоль/л на тлі діурезу більше 1500 мл/ добу, у 7 відбулося підвищення активності АЛАТ більше 60 Од/мл, АСАТ більше 50 Од/мл.

На тлі проведення інтенсивної терапії у 9 пацієнтів нормалізувались гемодинаміка, дихання та показники метаболізму. Одночасно на 4-5 добу після операції відновилась перистальтика та нормалізувався внутрішньочеревний тиск.

У інших 3 пацієнтів виникли хірургічні ускладнення, що зумовили виконання релапаротомії.

Отримані результати відповідають рекомендаціям $[1,5,6]$ при виявленні інтраабдомінальної гіпертензії (ІАГ) проводити лікування, спрямоване на забезпечення повноцінної оксигенації крові та стимуляцію діурезу. Показанням до декомпресійної релапаротомії $є$ відсутність зниження внутрішньочеревного тиску нижче 20 мм рт. ст., не зважаючи на проведення інтенсивної терапії впродовж 24 годин.

Підгрунтям такого підходу є механізм підвищення внутрішньочеревного тиску. Якщо в перші 24 годин після операції провідну роль у виникненні ІАГ відіграє механічне стиснення внутрішніх органів після тугого зашивання рани, то в термін 48 годин і пізніше це зумовлено паралічем перистальтики, бурхливим розмноженням в кишечнику газоутворюючих мікроорганізмів і виникненням нового особливого джерела інтоксикації.

У разі виконання операційного втручання на тлі анемії, гіпоксії АКС може виникнути вже через 36 годин після операції. Так, у 2 хворих після виконання абдомінального операційного втручання були низький артеріальний тиск на рівні 90/60 мм рт. ст. та олігурія на рівні 500 мл/12 годин на тлі введення впродовж цього часу 3-3,5 л розчинів електролітів.

В одному спостереженні стан хворого був помилково оцінений як неадекватне поповнення водно-електролітного балансу. Продовжена інтенсивна терапія з позитивним балансом 3200 мл. Ще через 12 годин виникла нестабільність гемодинаміки, яка змусила до дозованого постійного введення симпатоміметиків, констатовані анурія, високі рівні трансаміназ: аланінової (АЛАТ) 236 Од/мл, аспарагінової (АСАТ) 675 Од/мл на тлі анурії з рівнем креатиніну 291 мкмоль/мл, сечовини 8,1 ммоль/л. Одночасно за даними ультразвукової доплерографії та контрастної спіраль- 
ної комп’ютерної томографії спостерігали відсутність кровотоку по печінковій артерії. При цьому внутрішньочеревний тиск становив 11 мм рт. ст.

Через 36 та через 48 годин після операції внутрішньочеревний тиск становив 16,2 мм рт. ст., однак, зважаючи на нестабільність дихання, яка вимагала штучної вентиляції легень, вирішено зняти шви з апоневрозу черевної стінки. Надалі показники внутрішньочеревного тиску не перевищували 10 мм рт. ст.

В подальшому діагностований сепсис, для лікування якого послідовно, відповідно до антибіотикограми, застосовували курсове лікування меропенемом, левофлоксацином, лінезолідом. Проведення антибіотикотерапії 3 використанням чергового препарату супроводжувалось суттєвим покращанням стану пацієнта впродовж 3-4 діб, яке змінювалось відновленням сепсису протягом наступних 4-5 діб.

Однак, не зважаючи на відновлення адекватної оксигенації при самостійному диханні, нормалізацію рівнів АЛАТ та АСАТ, показники сечовини та креатиніну не повернулись до рівнів норми, не зважаючи на діурез більше 1,5 л на добу, а сепсис тричі рецидивував і врешті-решт зумовив смерть хворого.

Наведене спостереження яскраво висвітлює основну особливість АКС: виникнення незворотної ниркової недостатності та рецидивуючого сепсису. Рецидивуючий перебіг сепсису, ймовірно, є наслідком незворотного ураження стінки кишечнику, що супроводжувалось втратою нею бар’єрних, тобто імунних, функцій.

Викладене свідчить про важливість недопущення подібного ураження стінки кишечнику в періопераційному періоді.

Водночас оскільки субстрат ураження i, відповідно, його механізми не встановлені, запобіжні та лікувальні заходи досі грунтуються на результатах клінічних спостережень.

Згідно з міжнародним консенсусом [1], першочерговим $€$ встановлення назогастрального зонда, повноцінна седація пацієнта, уникнення надмірного введення лікувальних розчинів, встановлення нульового або навіть від'ємного рідинного балансу.

За недостатньої ефективності вказаних заходів рекомендоване зменшення ентерального харчування, застосування очисних клізм, введення гіпертонічних сольових та колоїдних розчинів iз метою зменшення набряку тканин, розміщення пацієнта в положення Тренделенбурга, за стабільної гемодинаміки застосування діуретичних препаратів.
У разі тяжкого перебігу АКС показані відмова від ентерального харчування, застосування декомпресії товстої кишки шляхом встановлення ректосигмоїдного катетера з інтервальним відсмоктуванням вмісту, застосування штучної вентиляції легень, пункційне видалення скупчень рідини під контролем ультразвукового дослідження або комп’ютерної томографії, застосування гемодіалізу.

Показанням до застосування декомпресійної серединної лапаротомії є зростання внутрішньочеревного тиску, встановлене шляхом щонайменше 3 вимірювань, та утримання його на рівні 20 мм рт. ст. впродовж медикаментозного лікування протягом 24 годин.

Ще у одного пацієнта після безнатяжної герніопластики великої післяопераційної грижі, на тлі серцевої недостатності 1-2 ст., атеросклерозу та цукрового діабету 2 типу впродовж двох діб мала місце нестабільність загального стану, для досягнення повноцінної оксигенації застосовували кисневу маску, не зважаючи на відсутність втручання на кишечнику, виник стійкий метеоризм з ІАГ на рівні 23 мм рт. ст., відмічено зростання рівнів сечовини та креатиніну в крові. Проведення дегідратаційної терапії одночасно з застосуванням постійної епідуральної анестезії на третю добу після операції дозволило впродовж 24 годин усунути всі патологічні явища і досягти швидкого одужання пацієнта.

Для прискорення загоєння ран та попередження ускладнень у пацієнтів, яким виконана декомпресійна лапаротомія, рекомендується застосування вакуумного відсмоктування [8, 9].

У пацієнтів з хірургічною патологією ІАГ не рідко спостерігається і зникає під впливом медикаментозного лікування [7]. Ускладнення ІАГ розвитком недостатності функції органів суттєво погіршує прогноз лікування, однак не є показанням до невідкладного здійснення декомпресійної лапаротомії, оскільки таке втручання не призводить до гарантованого усунення АКС. За даними [5], медикаментозне лікування супроводжувалось одужанням 33 та смертю 14 з 66 пацієнтів із встановленим діагнозом АКС, тоді як виконання декомпресійної лапаротомії у 19 хворих супроводжувалось одужанням 15 та смертю 4 з них.

Більше того, не встановлено, які патологічні зміни, викликані АКС, найбільш ефективно усуваються під впливом декомпресійної лапаротомії, взаємозв'язок між часом виконання декомпресійної лапаротомії та летальністю слабкий, а вагомість клінічних свідчень обмежена, розуміння патогенезу ураження недостатнє і потребує подальших досліджень [3]. 
Також потребує удосконалення тактика лікування КС кінцівок та інших ділянок тіла $[2,10]$.

Висновки. 1. Сильний біль в ураженій ділянці кінцівки, парестезії та рігідність м’язів, підвищення рівнів трансаміназ, сечовини, креатиніну, виявлення набряку м'язів за даними ультразвукового дослідження та томографії слід розглядати як ознаки розвитку КС.

2. Фасціотомія $є$ дієвим і необхідним, однак недостатнім заходом щодо усунення КС кінцівки,

\section{СПИСОК ЛІТЕРАТУРИ}

1. Intra-abdominal hypertension and the abdominal compartment syndrome: updated consensus definitions and clinical practice guidelines from the World Society of the Abdominal Compartment Syndrome / Andrew W. Kirkpatrick, Derek J. Roberts, Jan De Waele [et al.] and The Pediatric Guidelines Sub-Committee for the World Society of the Abdominal Compartment Syndrome // Intensive Care Med. - 2013. - Vol. 39 (7). - P. 1190-1206. DOI: 10.1007/s00134-013-2906-z PMCID: PMC3680657 PMID: 23673399.

2. Managing missed lower extremity compartment syndrome in the physiologically stable patient: A systematic review and lessons from a Level I trauma center / G. E. Glass, R. M. Staruch, J. Simmons [et al.] // J. Trauma Acute Care Surg. - 2016. Vol. 81 (2). - P. 380-387. DOI: 10.1097/TA.0000000000001107. 3. Lana Van Damme Effect of decompressive laparotomy on organ function in patients with abdominal compartment syndrome: a systematic review and meta-analysis / Lana Van Damme, Jan J. De Waele // Crit Care. - 2018. - Vol. 22. - P. 179. DOI: 10.1186/ s13054-018-2103-0 PMCID: PMC6060511 PMID: 30045753.

4. Clinical case of acute non-traumatic hand compartment syndrome and systematic review for the upper extremity / J. Ogrodnik, J. D. Oliver, D. Cani [et al.] // Hand (NY). - 2019. DOI: $10.1177 / 1558944719856106$.

5. How much does decompressive laparotomy reduce the mortality rate in primary abdominal compartment syndrome?

\section{REFERENCES}

1. Andrew W. Kirkpatrick, Derek J. Roberts, Jan De Waele, Roman Jaeschke, Manu L.N.G. Malbrain, Bart De Keulenaer, Juan Duchesne \& The Pediatric Guidelines Sub-Committee for the World Society of the Abdominal Compartment Syndrome (2013). Intra-abdominal hypertension and the abdominal compartment syndrome: updated consensus definitions and clinical practice guidelines from the World Society of the Abdominal Compartment Syndrome. Intensive Care Med., 39 (7), 11901206. DOI: 10.1007/s00134-013-2906-z PMCID: PMC3680657 PMID: 23673399.

2. Glass, G.E., Staruch, R.M., Simmons, J., Lawton, G., Nanchahal, J., Jain, A., \& Hettiaratchy, S.P. (2016). Managing missed lower extremity compartment syndrome in the physiologically stable patient: A systematic review and lessons from a Level I trauma center. J. Trauma Acute Care Surg., 81 (2), 380-387. DOI: 10.1097/TA.0000000000001107.

3. Lana Van Damme, \& Jan J. De Waele (2018). Effect of decompressive laparotomy on organ function in patients with abdominal compartment syndrome: a systematic review and meta-analysis. лікування якого має включати тривалий вплив на всі чинники його патогенезу.

3. Виникнення АКС слід зважити через 24-36 годин ускладненого перебігу запалення, посттравматичного або післяопераційного періоду.

4. Заходами попередження та початку лікування AKC є забезпечення високої оксигенації та перфузії тканин організму, усунення їх набряку. Виконання декомпресійної лапаротомії показане лише при збереженні ІАГ на рівні вище 20 мм рт. ст. після повноцінної інтенсивної терапії впродовж 24 годин.

A single-center prospective study on 66 patients / Muresan Mircea, Simona Muresan, Klara Brinzaniuc [et al.] // Medicine (Baltimore). - 2017. - Vol. 96 (5). - P. e6006. DOI: 10.1097/ MD.0000000000006006 PMCID: PMC5293461 PMID: 28151898.

6. Decompressive laparotomy for abdominal compartment syndrome / J. De Waele, E. Kimball, M. Malbrain [et al.] // Br. J. Surg. - 2016. - Vol. 103 (6). - P. 709-715. DOI: 10.1002/ bjs.10097.

7. Incidence of intra-abdominal hypertension and abdominal compartment syndrome: A systematic review / Z. Khot, P. B. Murphy, N. Sela [et al.] // J. Intensive Care Med. - 2019. Vol. 6. DOI: $10.1177 / 0885066619892225$.

8. Allegranzi B. New WHO recommendations on intraoperative and postoperative measures for surgical site infection prevention: an evidence-based global perspective / B. Allegranzi, B. Zayed, P. Bischoff // Lancet Infect Dis. - 2016. - Vol. 16. - P. 288-303. 9. Willy C. Closed incision negative pressure therapy: international multidisciplinary consensus recommendations / C. Willy, A. Agarwal, C. A. Andersen // Int. Wound J. - 2017. Vol. 14. - P. 385-398.

10. Alexander W. Acute lumbar paraspinal compartment syndrome: a systematic review / W. Alexander, N. Low, G. Pratt // ANZ J Surg. - 2018. - Vol. 88 (9). - P. 854-859. DOI: 10.1111/ ans.14342. Epub 2018 Jan 8.

Crit. Care, 22, 179. DOI: 10.1186/s13054-018-2103-0 PMCID: PMC6060511 PMID: 30045753.

4. Ogrodnik, J., Oliver, J.D., Cani, D., Boczar, D., Huayllani, M.T., Restrepo, D.J., Sisti, A., et al. (2019). Clinical case of acute non-traumatic hand compartment syndrome and systematic review for the upper extremity. Hand $(N Y)$. DOI: $10.1177 / 1558944719856106$.

5. Mircea Muresan, Simona Muresan, Klara Brinzaniuc, Septimiu Voidazan, Daniela Sala, Ovidiu Jimborean, Al Husseim Hussam et al. (2017). How much does decompressive laparotomy reduce the mortality rate in primary abdominal compartment syndrome? A single-center prospective study on 66 patients. Medicine (Baltimore), 96 (5), e6006. DOI: 10.1097/MD.0000000000006006 PMCID: PMC5293461 PMID: 28151898.

6. De Waele, J.J., Kimball, E., Malbrain, M., Nesbitt, I., Cohen, J., Kaloiani, V., Ivatury, R., Mone, M., Debergh, D., \& Björck, M. (2016). Decompressive laparotomy for abdominal compartment syndrome. Br. J. Surg., 103 (6), 709-715. DOI: 10.1002/ bjs.10097. Epub 2016 Feb 18. 
7. Khot, Z., Murphy, P.B., Sela, N., Parry, N.G., Vogt, K., \& Ball, I.M. (2019). Incidence of intra-abdominal hypertension and abdominal compartment syndrome: A systematic review. J. Intensive Care Med., 6. DOI: 10.1177/0885066619892225.

8. Allegranzi, B., Zayed, B., \& Bischoff, P. (2016). New WHO recommendations on intraoperative and postoperative measures for surgical site infection prevention: an evidence-based global

Електронна адреса для листування: sepodpryatov@yahoo.com perspective. Lancet Infect. Dis., 16, e288-e303.

9. Willy, C., Agarwal, A., \& Andersen, C.A. (2017). Closed incision negative pressure therapy: international multidisciplinary consensus recommendations. Int. Wound J., 14, 385-398.

10. Alexander, W., Low, N., \& Pratt, G. (2018). Acute lumbar paraspinal compartment syndrome: a systematic review. ANZ J. Surg., 88 (9), 854-859. DOI: 10.1111/ans.14342.

Отримано 17.04.2020

\title{
S. E. PODPRYATOV, V. P. KORCHAK, I. O. BELOUSO, S. S. PODPRIATOV, I. V. SATSIUK I. M. SLOBODIANIUK
}

Kyiv Municipal Hospital No. 1

\section{COMPARTMENT SYNDROME OF THE EXTREMITIES AND THE ABDOMEN}

\begin{abstract}
The aim of the work: to assume own experience on diagnostic and treatment of the compartment syndrome (CS) of the extremeties and the abdomen.

Materials and Methods. Five cases of CS were analysed.

Results and Discussion. Hand CS occur in 2 patients, lower limb - in 1, in all cases three weeks after the primary injury.

In 1 case after the dog's bite great increase in transaminases activity occurred. Full patient's recovery had been achieved by performing fascial compartment decompression and intensive anticlostridial antibacterial therapy during 23 days. In another case shoulder trauma while on warfarin treatment turn to swelling subfascial hematoma. Changing the anticoagulant type and performing of fasciotomy lead to full recovery. In both cases muscle destructuration and swelling were revealed by means of ultrasonic investigation. Validity of these signs should be cleared in further studies. In the third case CS appear as the result of total subcutaneal and interfascial thigh and leg phlegmona in the consequence of lymphedema complication. Thigh amputation had been made. Intraabdominal hypertension (IH) at the level of $20 \mathrm{~mm} \mathrm{Hg}$ or higher in first three days postoperatively had been seen in 12 patients. Intensive care leads to hemodynamic, breathing and abdominal tension normalizing in 9 cases. Surgical complications caused relaparotomy in 3 cases. Abdominal (A) CS occur in 2 cases. In one of that situation was wrongly estimated as uncompleted liquid-electrolyte balance and intensive therapy with positive liquid infusion of $3200 \mathrm{ml}$ had been prolonged. This resulted in kidney impairment and recurrent sepsis with the failed treatment during 27 days. In another case in time diagnostic and adequate treatment were speedily successful.

Limb and abdominal CS is a life-threatening condition with specific appearance which require special a treatment.
\end{abstract}

Key words: compartment syndrome; limbs; abdominal cavity.

С. Е. ПОДПРЯТОВ, В. П. КОРЧАК, И. О. БЕЛОУСОВ, С. С. ПОДПРЯТОВ, И. В. САЦЮК, И. М. СЛОБОДЯНЮК

Киевская городская клиническая больница № 1

\section{КОМПАРТМЕНТ- СИНДРОМ КОНЕЧНОСТЕЙ И БРЮННОЙ ПОЛОСТИ}

\begin{abstract}
Цель работы: оценить собственный опыт диагностики и лечения компартмент-синдрома (КС) конечностей и брюшной полости. Материалы и методы. Проведен анализ клинического течения, диагностики и лечения КС у 5 пациентов.

Результаты исследований и их обсуждение. КС верхней конечности наблюдали у 2 пациентов, нижней - у одного. У всех пациентов признаки КС возникли через 3 недели после первичного повреждения. В одного наблюдении после укуса собаки отмечено значительное повышение активности трансаминаз. Произведена декомпрессия фасциальных футляров и назначена антиклостридиальная антибактериальная терапия, что в течение 23 суток привело к выздоровлению. Во втором наблюдении травма плеча на фоне приема варфарина привела к нарастанию субфасциальной гематомы. Переход на применение другого препарата антикоагулянтного действия и выполнение фасциотомии сопровождались выздоровлением пациента. В обоих наблюдениях при ультразвуковом исследовании обнаружены утрата структурности и отек мышц. Патогномоничность этих признаков подлежит уточнению. У третьего пациента с тотальной подкожной и межмышечной флегмоной бедра и голени на фоне лимфостаза выполнена ампутация конечности на уровне бедра. Интраабдоминальную гипертензию (ИАГ) на уровне 20 мм рт. ст. и выше наблюдали в первые 3 суток после внутрибрюшной операции у 12 пациентов. Под влиянием интенсивной терапии в 9 наблюдениях гемодинамика, дыхание и внутрибрюшное давление нормализовались. У 3 пациентов возникли осложнения, потребовавшие выполнения релапаротомии. Абдоминальный компартмент-синдром (АКС) наблюдали у 2 больных. У одного пациента состояние ошибочно оценено как неадекватное восполнение водно-электролитного баланса. Продолжена инфузионная терапия с положительным балансом 3200 мл. В дальнейшем возникли почечная недостаточность и рецидивирующий сепсис, лечение которых в течение 27 суток оказалось неэффективным. Еще у одного больного своевременна диагностика и адекватное лечение АКС сопроводжались быстрым выздоровлением. КС конечностей и брюшной полости является опасным для жизни осложнением, имеет особенные признаки и требует специального лечения.
\end{abstract}

Ключевые слова: компартмент-синдром, конечности, брюшная полость. 